\title{
物理探査手法を用いた浅部不整形地盤構造の 推定と耐震設計への適用事例
}

\author{
野上 雄太 ${ }^{1}$ ・坂井 公俊 2 - 高橋 千佳 ${ }^{3} \cdot$ \\ 室野 剛隆 4 ・盛川 仁 5 ・佐藤 勉 6 \\ 1正会員 鉄道総合技術研究所 構造物技術研究部（干185-8540 東京都国分寺市光町2-8-38） \\ E-mail: nogami@rtri.or.jp \\ 2 正会員 鉄道総合技術研究所 構造物技術研究部（†185-8540 東京都国分寺市光町2-8-38） \\ E-mail:ksakai@rtri.or.jp \\ 3学生会員 東京工業大学大学院（干226-8502 神奈川県横浜市緑区長津田町4259） \\ E-mail:tchika@enveng.titech.ac.jp \\ 4正会員 鉄道総合技術研究所 構造物技術研究部（干185-8540 東京都国分寺市光町2-8-38） \\ E-mail:murono@rtri.or.jp \\ 5正会員 東京工業大学大学院准教授（２26-8502 神奈川県横浜市緑区長津田町4259） \\ E-mail:morika@enveng.titech.ac.jp \\ 6フェロー会員 鉄道総合技術研究所 構造物技術研究部（干185-8540 東京都国分寺市光町2-8-38） \\ E-mail:ben@rtri.or.jp
}

\begin{abstract}
耐震設計では, 特に不整形地盤などの特殊な地盤条件では, 正確な浅部地下構造を求め, 表層地盤の地 震時挙動を適切に評価した上で構造物を設計することが重要である．地下構造を推定するには，一般にボ ーリング調査が用いられる。しかし，ボーリング調査では工学的基盤の推定が困難な場合や既存の調査結 果を活用して工学的基盤を補間，推定する場合には，ボーリング調査に代わる手法で地盤構造を推定する ことが考えられる。本報告では，広域な不整形地盤において，ボーリング調査を行ったにも関わらず，工 学的基盤が推定できなかった地域を対象として, 微動探査法, 重力探査法を用いて工学的基盤を推定した 後, 得られた地盤構造に対して非線形動的FEM解析を行って地表面設計地震動を推定した事例について述 べる.
\end{abstract}

Key Words : engineering bedrock, microtremor survey, gravity survey, surface ground motion, two-dimensional dynamic FEM analysis

\section{1. はじめに}

鉄道構造物の而震設計（以下，耐震設計標準） ${ }^{1)}$ では, 而震設計上の基盤面（工学的基盤面）と呼ばれるせん断 波速度が $400 \mathrm{~m} / \mathrm{s}$ 程度の地盤において標準地震動が設定 されており，工学的基盤以浅の影響はサイト毎に適切に 評価を行うこととしている。 これは地表面地震動が工学 的基盤以浅の影響を特に強く受けることに配慮したもの である．既往の鉄道の地震被害事例を見ても，特に，堆 積層が厚い場合，不整形な地盤構造の影響を無視できな い場合，特殊土が堆積している場合などでは，局所的に 地震動が増幅するなどして，被害が局所的に発生するこ

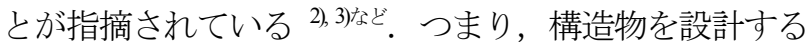
際には設計地点ごとに正確な浅部地下構造を求め, 工学 的基盤以浅の地震時挙動を詳細に検討することが重要で
ある。

地下構造推定手法としては一般的にボーリング調查が 用いられるが，地盤条件が悪い地域等では工学的基盤が 深いために通常のボーリング調査では工学的基盤の位置 を得ることが困難な場合がある。こういった場合にはボ ーリング調査に代わる他の手法によって地盤構造を推定 する必要がある．ボーリング調査以外の地盤構造推定手 法としては，人工地震探査法 ${ }^{4)}$, 表面波探査法 ${ }^{5}$, 微動 探查法 ${ }^{9}$, 重力探査法 》など種々の物理探査手法が提案 され，利用されてきた．しかし，これらの手法の多くは 主に地款や地震基盤（せん断波速度 $2.5 \sim 3.5 \mathrm{~km} / \mathrm{s}$ 程度） といった非常に深い地盤形状を推定することを目的とし て用いられることが多く，また，浅部構造を推定する場 合においても，地震記録の考察や，サイト増幅特性の評 価など，地震学的なアプローチからの利用がほとんどで 


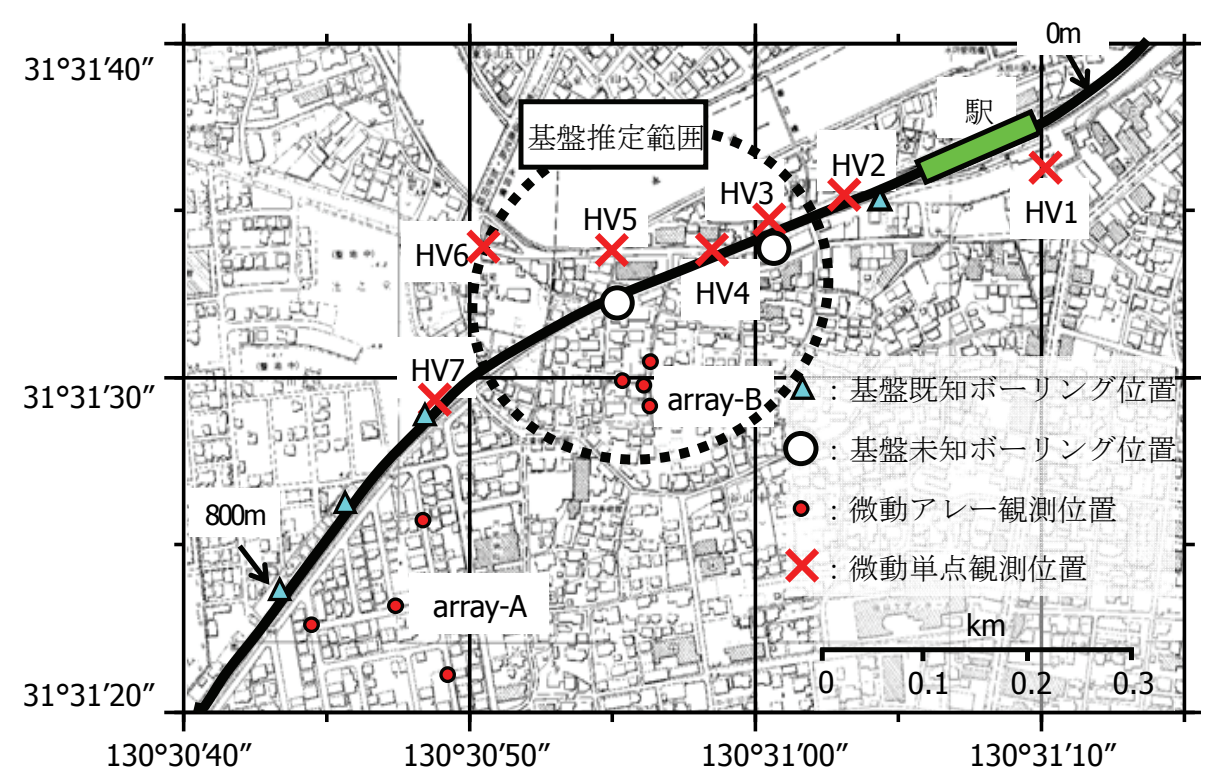

図-1 ボーリング探査, 微動探査位置（緯度経度は世界測地系）

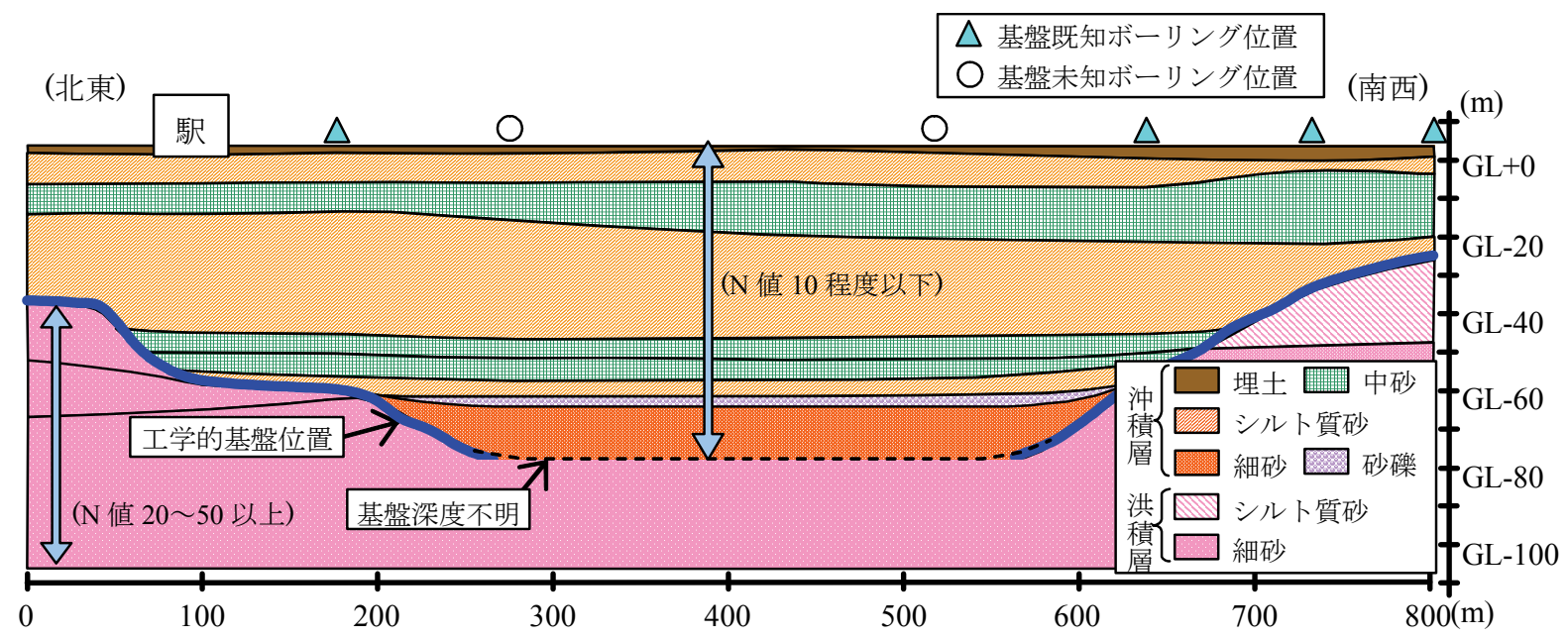

図-2 対象地域の地質縦断図

あり，一般的な土木構造物の耐震設計の実務において， これらの手法を適用して工学的基盤を推定し，得られた 地盤構造を用いて地表面設計地震動を設定した事例はこ れまでほとんどないと言える。

本研究では，特殊土（シラス地盤）かつ堆積層が厚

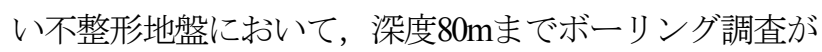
実施されたにも関わらず，工学的基盤まで到達していな い地域に対して，微動探査および重力探査の実施，工学 的基盤深度の推定，設計用地震動の設定，という一連の 流れを実施したささらに，工学的基盤を正確に推定する ことの重要性を簡単な数值解析結果を通して示す. 個々 の解析手法については，いずれも既知の技術であるが, 工学的観点からこれらを統合し, 設計用地震動の作成の ために実践的に活用し，その重要性を示すことは今後の 設計用地震動を設定する際の重要な資料となるものと考 えられる.

\section{2. 対象地域の概要}

解析対象地域の既往のボーリング調査位置，後述する 微動観測点を図-1 に，地質縦断図を図-2 に示す。対象 地域では約 $100 \mathrm{~m}$ 間隔で工学的基盤深度，土の物性值把 握のためのボーリング調査が実施されている，その結果， この地域は大きく分けて $\mathrm{N}$ 值が $0 \sim 10$ 程度の軟弱な埋土, 沖積シラス層（シルト質砂，細砂，中砂，砂礫）が厚く 堆積し, その下に主に $\mathrm{N}$ 值 50 以上の洪積層（シルト質 砂，細砂）が堆積している土層構成となっている. また， この地域の工学的基盤面は傾斜しており，図-2 に点線 で示したエリアは，深度約 $80 \mathrm{~m}$ のボーリング調査を実 施しても， $\mathrm{N}$ 值 10 程度の層が連続しており，工学的基 盤に到達していない.

この地域における地表面設計地震動を評価するために は，工学的基盤の構造を正確に把握しておく必要がある. 
表-1 探索範囲 (array-A)

\begin{tabular}{|c|c|c|}
\hline 層番号 & $\begin{array}{c}\text { せん断弾性波速度 } \\
(\mathrm{m} / \mathrm{s})\end{array}$ & 層厚 \\
\hline 1 & $130-170$ & $1-100$ \\
\hline 2 & $195-235$ & $1-100$ \\
\hline 3 & $440-460$ & $1-100$ \\
\hline 4 & $1130-1150$ & $\infty$ \\
\hline
\end{tabular}

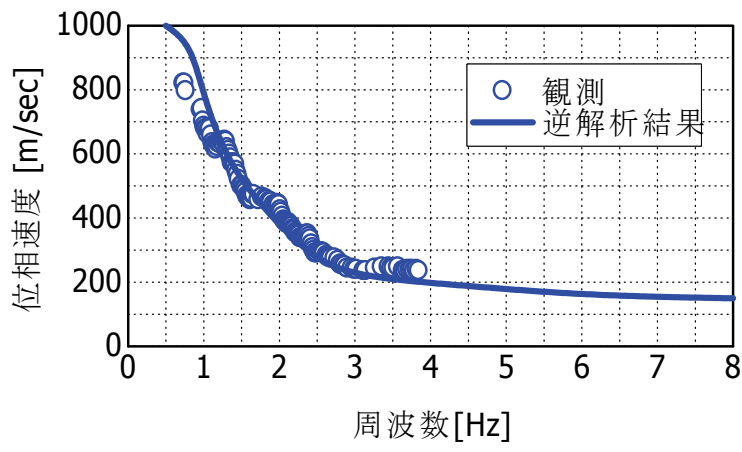

図-3 観測および推定位相速度（array-A）

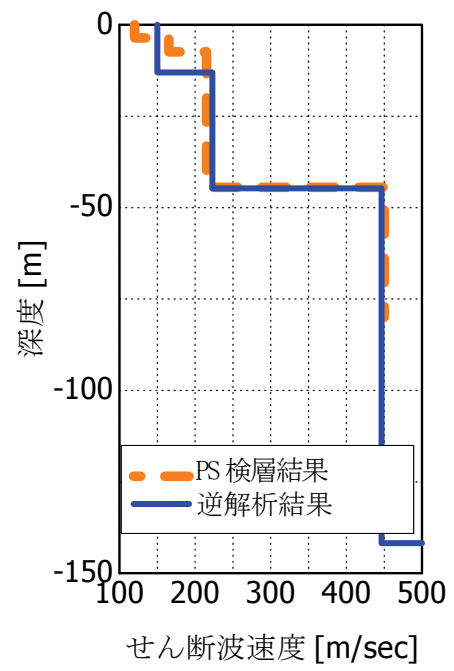

図-5＼cjkstart推定された地盤構造（array-A）

さらに，工学的基盤が傾斜しているために，1次元解析 結果では複雑な波動伝播の影響を評価できない可能性が ある. よって，ボーリングに代わる手法によって基盤形 状を推定した後に, 得られた地盤構造を用いて2次元地 震応答解析を実施し, 地表面設計地震動を評価する.

\section{3. 工学的基盤の推定}

\section{(1) 微動探査}

微動探査法は，自然に豊富に存在し，その観測も容 易な常時微動に含まれる表面波を利用した地下構造探查 法である．地表面に展開したアレ一観測網によって微動
表-2 探索範囲 (array-B)

\begin{tabular}{|c|c|c|}
\hline 層番号 & $\begin{array}{c}\text { せん断弾性波速度 } \\
(\mathrm{m} / \mathrm{s})\end{array}$ & 層厚 \\
\hline 1 & $180-220$ & $1-100$ \\
\hline 2 & $280-320$ & $1-100$ \\
\hline 3 & $440-460$ & $1-100$ \\
\hline 4 & $1130-1150$ & $\infty$ \\
\hline
\end{tabular}

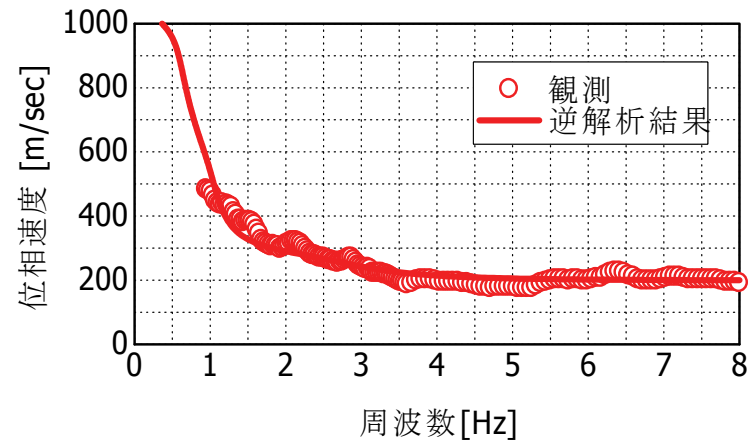

図-4 観測および推定位相速度（array-B）

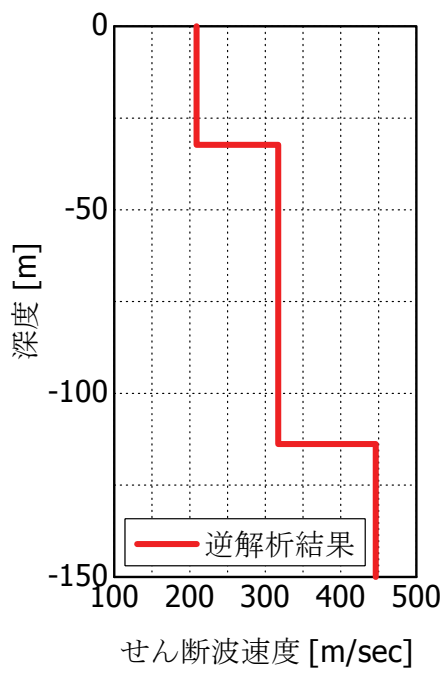

図-6 推定された地盤構造（array-B）

を観測し，アレー直下の地下構造を反映した表面波の位 相速度の分散特性を検出し，その分散特性の成因となる 地下構造を推定寸る手法であり, 数多くの適用事例があ

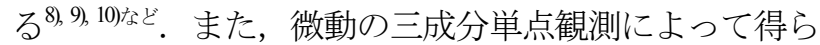
れた水平成分と鉛直成分のスペクトル比（以下， $\mathrm{H} / \mathrm{V}$ と 呼ぶ）に関する研究も数多く行われており，得られた H/Vから地盤構造を推定する手法もいくつか提案されて (るる11,12)など.

\section{a) 微動アレ一観測}

微動アレ一観測は，図-1に示す2地点(array-A，array-B) で実施した． array-A付近ではボーリング調査によって基 盤深度が44mと推定されているが， array-B付近では深度 80mまでのボーリング調査によっても基盤まで到達して 
いない. 使用した計測機器は, 換振器として固有周期1 秒の動コイル型速度計，ローパスフィルタ付きの増幅器， 記録器として16bit ディジタルレコーダーであり，各観 測点の同期をとれるようGPS時計が出力するスローコー ドを記録するシステムとした．各観測点での記録の同時 性に関する誤差はサンプリング周波数 $(500 \mathrm{~Hz})$ 以下であ る. 増幅器のローパスフィルタは全ての機器で同一のも のを使用している．また，外気温の影響を受け観測中に 計測器の特性が変化してしまうことを危惧し，観測の途 中に地震計の設置状況を確認し，適宜調整を行うことで， 記録の精度を確保した．観測は交通振動などの雑音が比 較的少ない深夜に実施した。アレー半径は，array-Aで 66m，40m，20m，array-Bで20m，10m，5mとした。なお， 一般的には，工学的基盤深度が深いと予想される のアレー半径を大きくするのがよいと考えられる。しか し, array-B付近は住宅が密集しており, 測定用地が十分 確保できないという問題があった。そこで，ボーリング 調査で把握している深度 $80 \mathrm{~m}$ 以上の構造推定が可能な範 囲で，できる限り大きなアレー半径を確保することとし， 上記のアレー半径を設定した．設定したarray-Bのアレー 半径では，十分な精度のデータが得られない可能性もあ るため，後述するH/Vを用いた検討や，重力探査による 推定結果を総合的に判断して最終的な工学的基盤深度を 推定している.

\section{b) 位相速度の算出}

微動観測で得られた上下動記録から，空間自己相関法 (Spatial Auto-correlation Method; SPAC 法) ${ }^{13)}$ 用いて Rayleigh 波の基本モードの位相速度を推定した. 得られ た位相速度を図-3，図-4 に丸印で示寸，なお，図は用 いた動コイル型速度計の固有周波数 $1 \mathrm{~Hz}$ よりも低い周 波数に対してもプロットしているが，計器の設置状態で の計器特性を記録して, 後処理によって計器補正するこ とで，センサーの固有周期の 5 倍程度までの周期領域で 十分な精度で観測可能である事を確認している.

\section{c）基盤深度の推定}

前項で得られた位相速度を満足する地盤構造を逆解析 によって推定する. 逆解析の手法としては遺伝的アルゴ

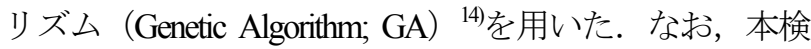
討では解析対象としていない極表層, 深部地盤に解が左 右されることの無いよう, PS 検層結果を参考に速度を ある程度固定して，層厚の推定を行っている. GA のパ ラメータは個体数 20 , 交差確率 $70 \%$, 世代数 100 とし た. 目的関数としては,

$$
\varepsilon=\frac{1}{K} \sum_{i=1}^{K}\left[C_{o b s}\left(f_{i}\right)-C_{c a l}\left(f_{i}\right)\right]^{2} \rightarrow \min
$$

とする $V_{s}, H$ を求める.ここで $V_{s}$ は地盤のせん断波速

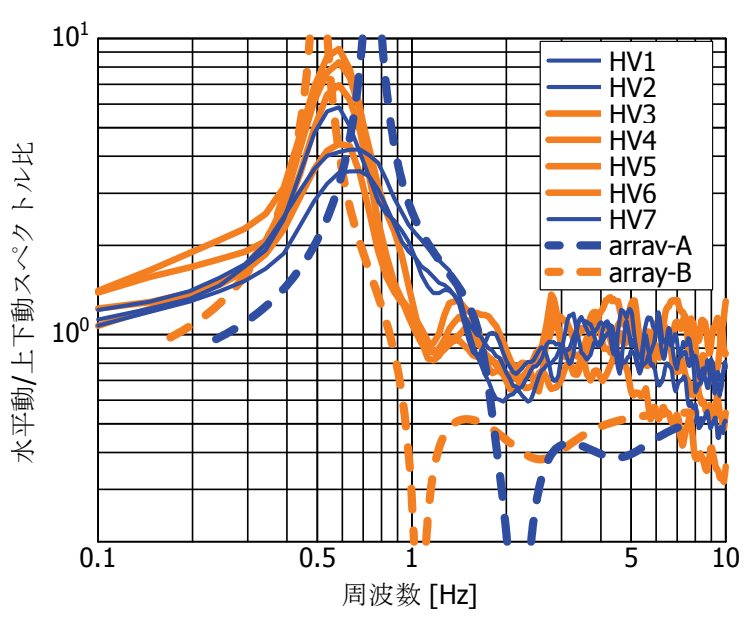

図-7 観測および推定 $\mathrm{H} / \mathrm{V}$

度， $H$ は層厚， $f_{i}$ は位相速度を与える $i$ 番目の振動数, $K$ は観測によって得られた位相速度を与える振動数の 個数, $C_{o b s}\left(f_{i}\right), C_{c a l}\left(f_{i}\right)$ はそれぞれ位相速度の観測值, 及び地盤モデルから計算される理論值である。この操作 を初期乱数を変えてそれぞれ独立に 10 回繰り返し，最 終的に得られた 10 個の構造から, 各適応度に対寸る加 重平均を取り, 微動アレ一観測から推定される構造とし た. なお， 4 章の地震応答解析に用いる工学的基盤深度 は，ここで推定された深度ではなく，後述する重力探査 や既往の土質関係資料等から総合的に決定している.

まず，基盤深度が既知の array-A に対して本手法を適 用し，手法の妥当性を確認する. GA による解の探索範 囲を表-1 に示寸．推定された地盤構造と PS 検層結果を 重ねたものを図-5に，推定した地盤構造から得られる 位相速度と観測記録の比較を図-3 に示寸，図-5 を見る と，推定した基盤深度は $45 \mathrm{~m}$ であり，標準貫入試験（N 值）により得られた基盤深度（44m）とほぼ一致してい る. また, 図-3 より, 得られた構造は観測された位相 速度をよく満足している。つまりこの地域において得ら れた位相速度から推定される地盤構造は，比較的高い精 度を持っているものと考えられる。

続いて, array-A と同様の手法を用いて array-B（基盤 深度未知点）での基盤深度を推定する. 探索範囲を表-2 に示寸. 逆解析の結果得られた地盤構造を図-6に, 得 られた構造から計算される位相速度と観測記録の比較を 図-4 に示す．計算で得られた位相速度の分散曲線は, 観測值をよく説明できており，実際の地盤構造を良好に 推定できたものと考えられる.このことから, array-Bで の基盤深度は $110 \mathrm{~m}$ であると推定した.

\section{d) $\mathrm{H} / \mathrm{V}$ による検討}

検討対象地域周辺で微動の三成分単点観測も実施して いる（図-1 の HV1〜HV7）。H/Vは単点観測によって得 られるため, アレー観測と比較して容易に実施可能とい 


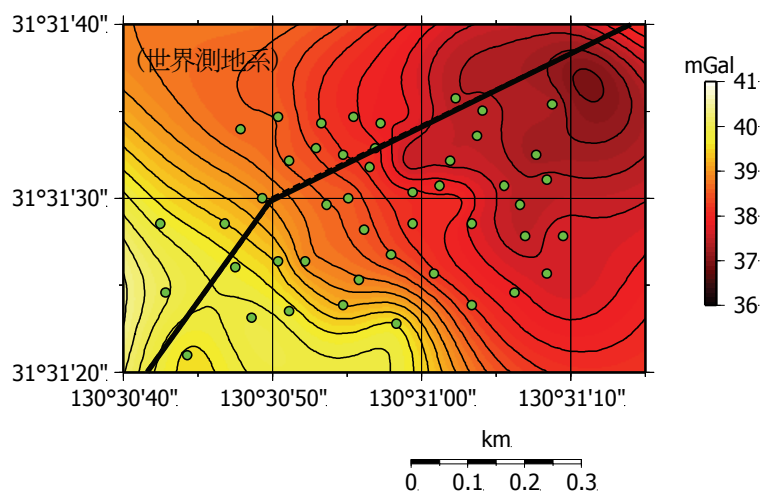

図-8 重力観測点およびブーゲー異常分布 （コンター間隔 $0.2 \mathrm{mGal}\left(10^{5} \mathrm{~m} / \mathrm{s}^{2}\right) ， 太$ 線は鉄道線路を示寸)

う利点がある。しかし $\mathrm{H} / \mathrm{V}$ は位相速度と比較して非常 に多くの分岐が存在し，この結果のみから正確な地盤構 造を得ることは難しいと考えられる．よって本検討では H/V から構造を推定寸るのではなく, 位相速度によって 推定された構造について妥当性の確認を行うとともに, 基盤深度の空間分布についても議論を行う．各観測点で 得られた $\mathrm{H} / \mathrm{V}$ を図-7 にまとめて描く.なお，ここでい う水平成分 $\mathrm{H}$ はスペクトルの水平 2 成分（NS，EW）の 算術平均を用いている.さらにこの図には array-A，Bに おいて推定された構造より計算される $\mathrm{H} / \mathrm{V}$ も破線で重 ねて描いてある。 $0.5 \mathrm{~Hz}$ 辺りのピークは本検討では対象 としない深い構造を反映したものであると考えられるの で，今回は $1 \mathrm{~Hz}$ 以上の振動数に限定して議論する. HV1, 2, 7 (図-7 の青色細線) では 2.1Hz あたりにディップ, 3〜4Hz あたりにピークが存在する. この傾向は array-A における結果と調和的である. また，HV3〜6（図-7 の 黄色太線）における $1.2 \mathrm{~Hz}$ あたりのディップ，1.7Hz あ たりのピークは array-B における結果と概ね一致してい る. これらの山や谷は工学的基盤の浅深によるものと考 えられるが，この結果より対象範囲の中心部（HV3〜 6）では基盤が急激に深くなっており，その他の地域で は基盤が浅くなっていると想定される。この傾向はボー リング調查, 微動アレー探査の結果とほぼ一致している.

\section{(2) 重力探査}

ニュートンの万有引力の法則に従って，2 質点間には 重力が働く. 重力は直下の影響を最も強く受けるため, 地下の密度構造が空間的に変化するような地域では，重 力もそれに合わせて変化する. この重力の空間的な変化 を測定することによって, 地下の不均質構造を推定する 手法が重力探査である. 重力探査からは地盤の密度構造 しか得られない，多層構造の推定が困難である等の短所 があるものの, 反射法，屈折法，微動アレ一などと比較 すると，機材の可搬性が高く，容易に観測可能であると いう利点を持っているため, 広域での概略的な地盤の 3

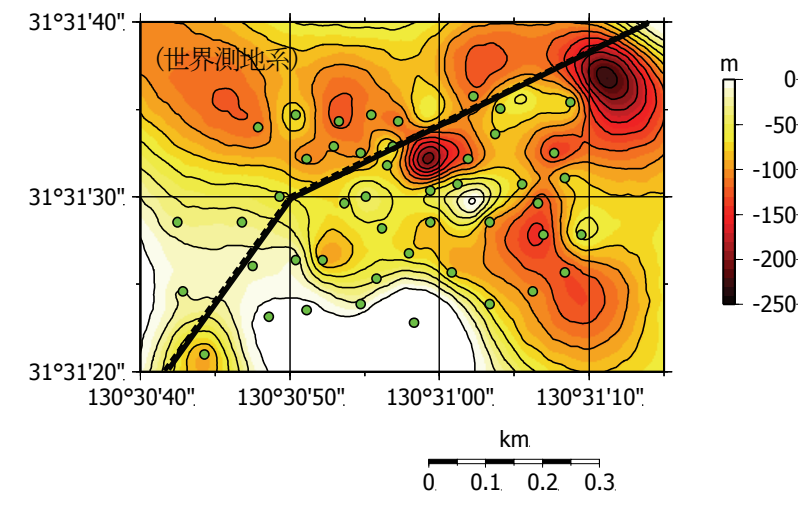

図-9 基盤深度分布 (コンター間隔 $20 \mathrm{~m} ， 太$ 太線は鉄道線路を示す)

次元構造を推定する際に，有効な手法のひとつである.

\section{a) 重力観測}

重力測定は ZLS 社製 Burris 自動重力計（公称分解能 $1 \mu \mathrm{Gal}$ ，フィールドでの実用分解能 $10 \mu \mathrm{Gal}$ 程度）を使用 した. 観測した測点数は図-8 に丸印で示寸 45 点であり, 対象地域周辺を約 $100 \mathrm{~m}$ 間隔で測定した。 なお，対象地 域内には，重力に影響を及ぼすことが䀣念されるような 重く大きな構造物等は存在しない，また重力探査では測 定点の位置，特に標高を正確に決定する必要があり，そ のために GPS 受信器(Ashtech ProMark2)をディファレンシ ヤルモードで使用した。これにより位置は水平方向で $10 \mathrm{~cm}$ 程度, 標高で $1 \mathrm{~m}$ 以内の精度で決定されている.

\section{b) ブーゲー異常の算出}

重力観測によって得られたデータに種々の補正を施し, ブーゲー異常を求めた ”。 基盤の重量は $21 \mathrm{kN} / \mathrm{m}^{3}$ と仮定 した. 解析は観測された 45 点での重力值に加えて, 既 往の観測結果 ${ }^{15}$ から対象地域周辺のデータを 6 点選択し, 計 51 点で行っている. 得られたブーゲー異常分布を図一 8 に示す. 図-8 より, 北東から南西方向にブーゲー異常 值が大きくなる傾向を示していることが分かる. さらに 解析領域の中心部では，ブーゲー異常が複雑に変化して おり，東に進むに従い基盤が深くなっていること，この 地域では基盤形状が複雑になっていることが予想される. また，線路直角方向（北西〜南東方向）ではブーゲー異 常の変化は小さいため, 対象地域における基盤形状の変 化は線路方向のみを考慮すればよいと考えられる.

\section{c）基盤深度の推定}

重力観測によって得られたブーゲー異常を満足する構 造を推定する. 逆解析手法としては二次元定量解析》を 用いた．このとき，0〜300mの上方接続法によるフィル ターをかけて表層の構造の影響のみを抽出して解析して いる. 出来る限り正確な解析結果を得るために, ボーリ ング調査で基盤深度が既知である4点をコントロールポ イントとして与えた. 堆積層の重量は $18 \mathrm{kN} / \mathrm{m}^{3}$ とした. 得られた基盤深度分布を図-9に示寸。この地域の基盤形 


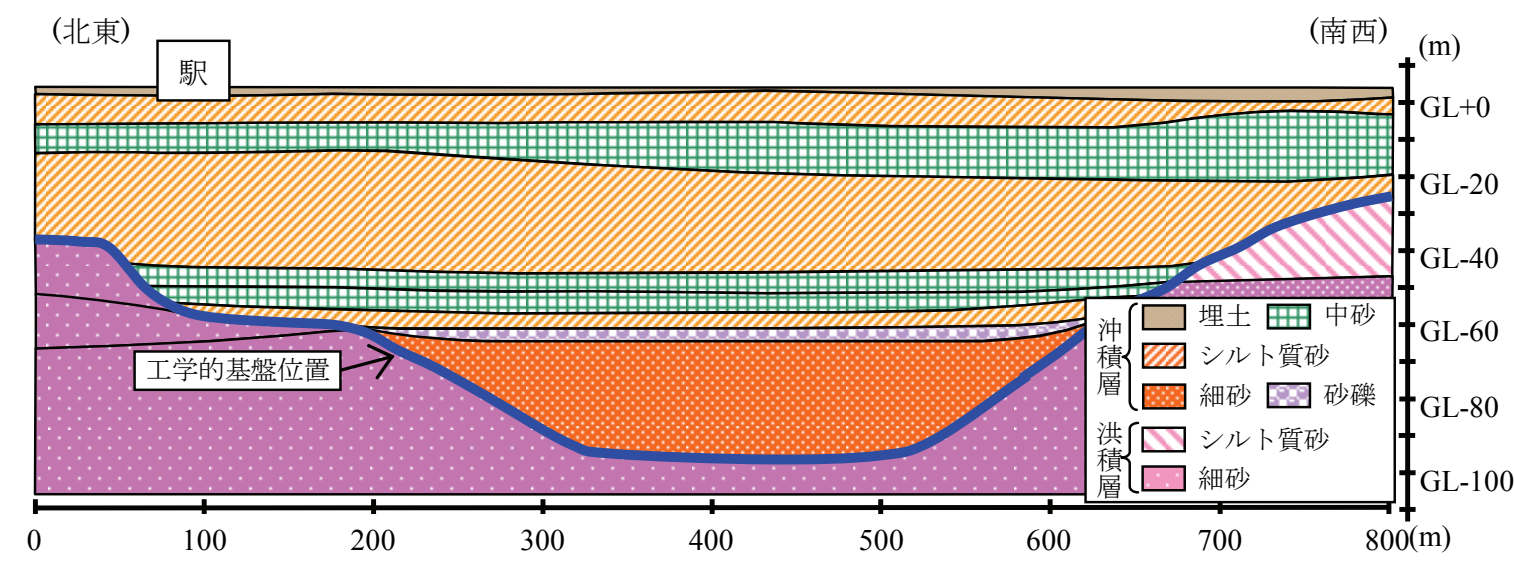

図-10 推定した工学的基盤面

状は非常に複雑である．ただし，局所的な基盤構造の変 化は，観測点が存在しない点における補間等が原因であ ると考えられる. こういった部分を除いた全体的な傾向 を見ると，ブーゲー異常分布から予想されるとおり，東 に進むに従い基盤が深く沈み込んでいることが分かる. ボーリング調査における基盤未到達点付近では，基盤深 度が100〜130mの範囲で分布していることが分かる.こ の結果は微動による推定結果と調和的である.

\section{(3) 設計に用いる工学的基盤深度}

本章では，ボーリング調查では工学的基盤深度が特定 できなかった地点における基盤深度を推定するために微 動観測および重力観測を行った. 重力観測から推定され た基盤深度はGL-100〜 130m 程度である. 微動観測から 推定された基盤深度はGL-110m程度であり，両者は調和 的である. よって，工学的基盤深度はGL-100〜130mの 間に設定するのが妥当であると考えられる，別途検討を 行った結果, 本検討の場合には, 工学的基盤深度をGL$100 \mathrm{~m}$ とすることで設計上安全側の地震動が評価される ことが分かっているため, 次節における地表面設計地震 動の評価に用いる工学的基盤深度をGL-100mとした. 評 価に用いた工学的基盤面の形状を図-10に示す.

\section{4. 地表面地震動の推定}

これまでの検討から, 対象地域の地盤構造が推定され た. 本章では地震応答解析を実施することで, 地表面設 計地震動の算定を行うとともに，今回行った工学的基盤 の推定結果が地表面地震動を評価寸る際にどのような影 響を与えるのかについて考察を行う。

\section{(1) 解析条件}

\section{a) 解析モデル}

解析手法としては2次元動的FEM解析を用いた. 解析

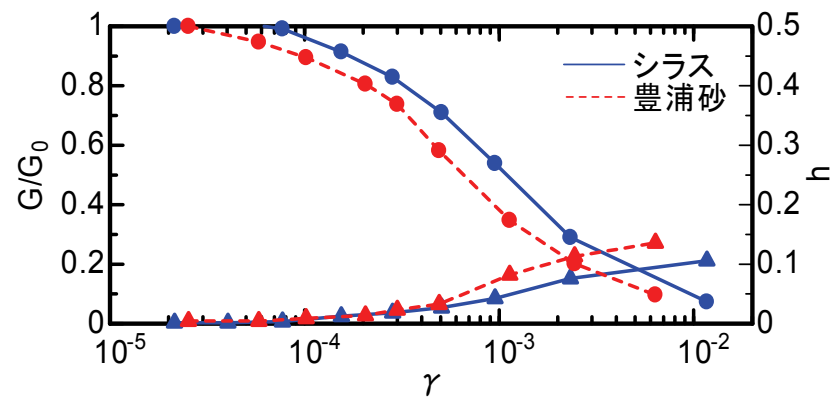

図-11 動的変形特性

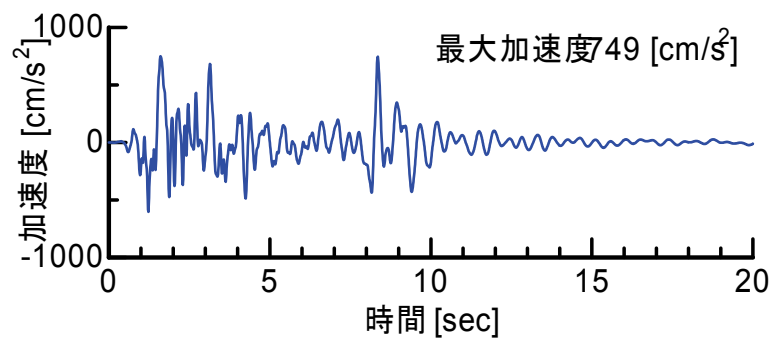

(a) 時刻歴波形

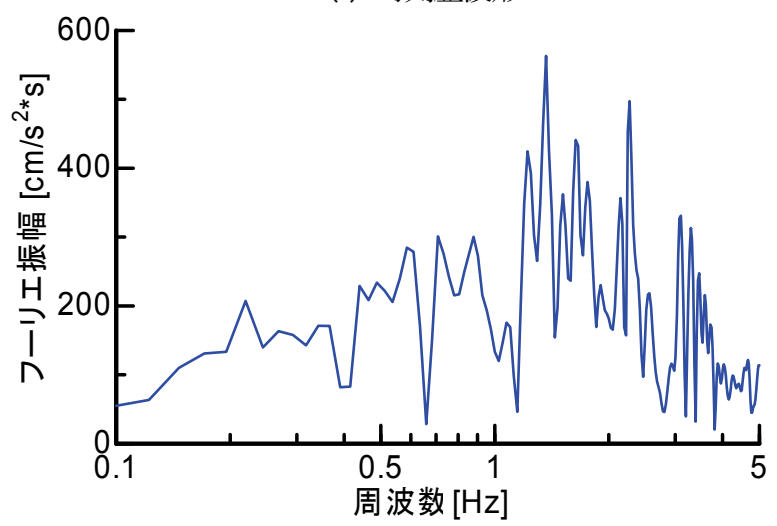

(b) フーリエ振幅スペクトル

図-12 基盤入力地震動

領域は幅 $800 \mathrm{~m} \times$ 深さ $110 \mathrm{~m}$ （図-10の縦断図に示した領 域）とし，5Hz程度までの信頼性を確保できるように要 素分割を行った. 一般的な鉄道構造物に影響を与える周 波数帯域は十分にカバーされている。側方境界は等変位 境界，底面境界は粘性境界とした，減衰は固有值解析に

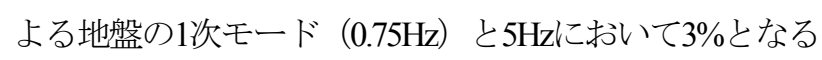



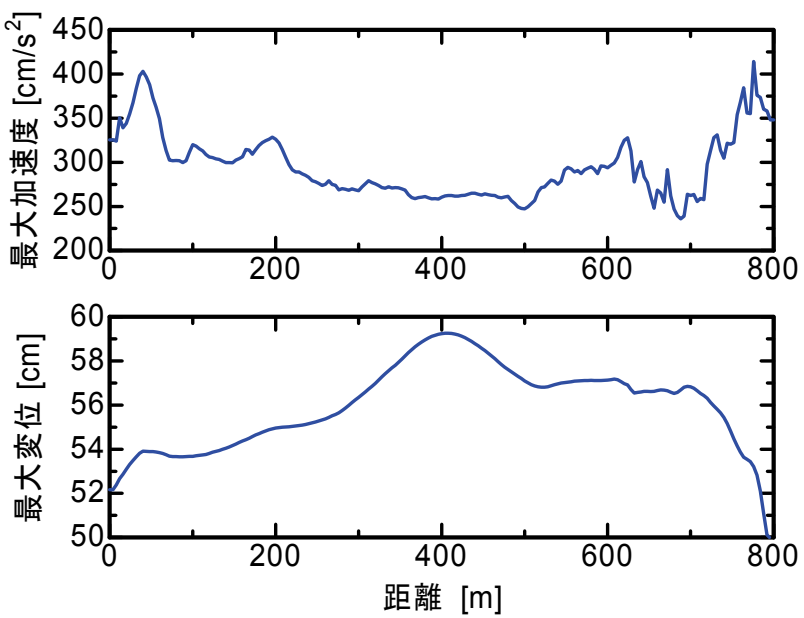

図-13 地表面最大加速度, 最大変位分布

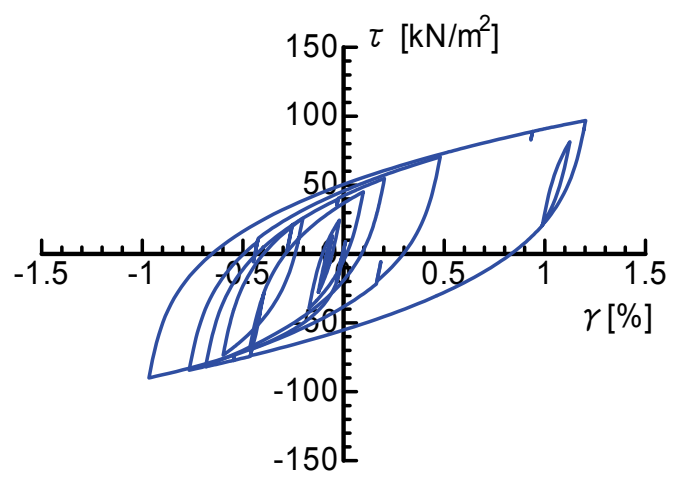

図-14 シラス層の応力ーひずみ関係

\section{ようにレイリー減衰で設定した。}

\section{b) 地盤モデル}

地盤は非線形性を考慮し，構成則として修正 RO モデ ル 16を用い，履歴則に Masing 則を適用した。 この時の 規準ひずみ $\gamma_{r}$ は $G / G_{0}=0.5$ となるときのひずみとして定 義した. この修正 RO モデルのパラメータは, 動的変形 特性試験が実施されている層については, 試験結果に最 もよく一致するように設定した．試験值が得られていな

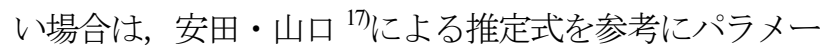
タを設定した。

ここで, 繰り返し三軸試験によって動的変形特性が得 られているシラスの $G / G_{0} \sim \gamma$ 関係, $h \sim \gamma$ 関係を図-11 に 示寸.この図には試験時の拘束圧がほぼ等しい豊浦砂 ${ }^{18)}$ の結果も併記している. 対象地域のシラスは, 豊浦砂と 比較すると, 同一ひず夕における剛性低下率は小さい. また，ひずみレベル $1.0 \times 10^{-3}$ 以降の減衰定数は，シラス のほうが小さい特性を持っていることが分かる.

\section{c) 入力地震動}

工学的基盤へ入力する地震動としては, 経験的グリー ン関数法等の手法を用いてサイト特有の地震動を用いる ことが望ましい，しかし，本検討では耐震設計標準 ${ }^{1} に$ おける一般的な手順に従い，L2 地震動スペクトル II 適

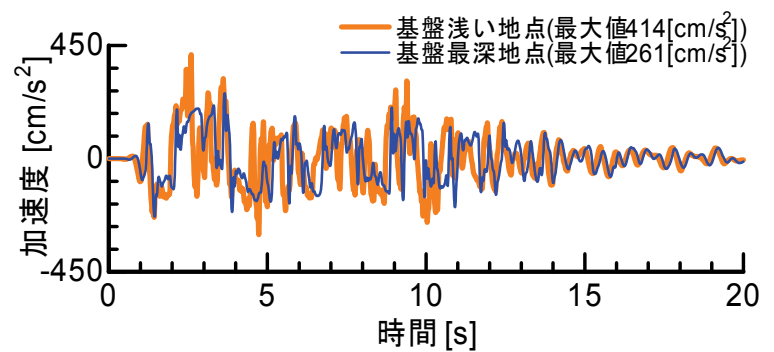

(a) 加速度波形

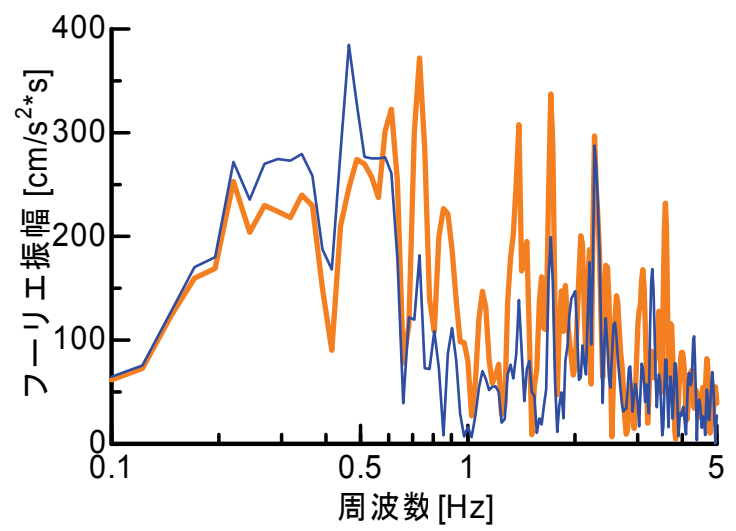

(b) フーリエ振幅スペクトル

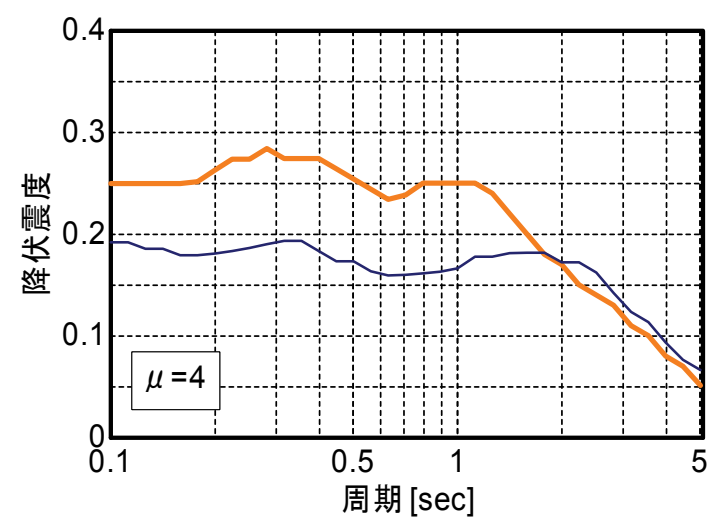

(c) 所要降伏震度スペクトル

図-15 地表面応答值の比較

合波を用いた。時刻歴波形およびフーリエ振幅スペクト ルを図-12 に示す．なお，本検討では加振方向を面内と している.

\section{(2) 解析結果}

解析結果として，地表面最大加速度および最大変位分 布を図-13 に示寸. 最大加速度, 最大変位ともに, 解析 対象範囲において複雑に変化している. 最大加速度は, 工学的基盤が深くなるにつれて小さくなっており, 工学 的基盤が最も深い距離 $400 \mathrm{~m}$ 付近では $250 \sim 300 \mathrm{~cm} / \mathrm{s}^{2}$ 程度 である．これとは逆に，最大変位は工学的基盤が深くな るにつれて大きくなる傾向にあり，距離 400m 付近では 約 $60 \mathrm{~cm}$ の変位を示している．ここで，大きなひずみを 示した距離 400m, 深度 GL-50m 付近のシラス地盤の応 
力-ひずみ関係を図-14 に示す．ひずみは $1 \%$ を超える值 を示しており，地盤が塑性化して岡性が低下しているこ とが確認できる. 最大加速度が入力地震動に比べて小さ く, 最大変位が $60 \mathrm{~cm}$ と大きな值を示寸原因としては, 土の非線形化が顕著なためであると推察される.

次に, 基盤最深地点（基盤深度 $100 \mathrm{~m}$, 図-10の距離 400m位置）と基盤の浅い地点（基盤深度 $30 \mathrm{~m}$ ，図-10の 距離 $750 \mathrm{~m}$ の位置) における地表面時刻歴応答波形， フ 一リエ振幅スペクトル，応答塑性率4の場合の非線形応 答スペクトルを図-15に示す．両地点ともに地盤の非線 形化によって長周期成分が卓越しており，1.0Hzより高 い振動数成分が小さくなっている. 特に基盤の深い地点 ではその影響が顕著となっており, 基盤の浅い地点と比 較して, 相対的に高い振動数で応答が小さくなっている 逆に，低い振動数側では基盤が深い地域では浅い地域よ りも大きく応答している．基盤が浅い地点と深い地点の 最大加速度には，1.6倍程度の差がある．また，非線形 応答スペクトルについても同様の傾向が見られ，例えば, 周期 0.4 秒程度, 応答塑性率 4 の構造物に要求される降伏 震度は，基盤の浅い地域と深い地域では，1.5倍程度の 差がある，以上より，谷状に基盤梁度が深くなっている 場所においては，比較的近い地点においても地表面の地 震動レベルが大きく変化する可能性があることが分かる. なお，本検討ケースでは，地盤の非線形化の影響が卓越 しており, 基盤の深い地点の加速度が小さくなる結果が 得られたが, 対象とする地盤条件に応じて, 非線形化の 程度，不整形性の影響などが複雑に影響するために，基 盤が深いと, 必ず加速度が小さくなる分けではない。

\section{（3）基盤深度の推定精度が地震動に与える影響}

ボーリング調査によって工学的基盤深度が推定できな い場合, ボーリング最深到達点を工学的基盤位置として 設定してしまう可能性がある. そこで工学的基盤深度の 推定精度が地表面の地震動評価にどのような影響を及ぼ すのかについて検討を行う，基盤深度としては，ボーリ ングの掘削深度 (約 $80 \mathrm{~m}$ ) と物理探査を用いて推定され た結果（約 $100 \mathrm{~m} ）$ のケースを設定し，両者の結果を比 較する，なお，本検討では，基盤深度の違いが結果に及 ぼす影響を知ることを目的としているため，地盤は全て 線形の条件で解析を行った. 両ケースの基盤深度分布を 図-16に示寸，両地盤において地震応答解析を実施した 結果, 得られた各地点における地表面最大加速度, 最大 変位分布を図-17に示す．基盤が傾斜している影響によ り, 最大加速度, 変位が複雑な分布となっている.また, 物理探査手法を用いて推定された基盤を与えた結果とボ ーリング掘削長を基盤深度とした結果では, 地表面での 地震動に $5 \%$ 程度の違いが見られる. 今回の検討では基

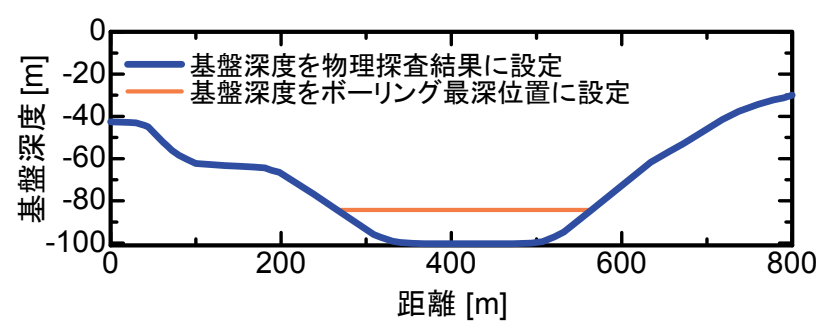

図-16 解析に用いた基盤深度分布
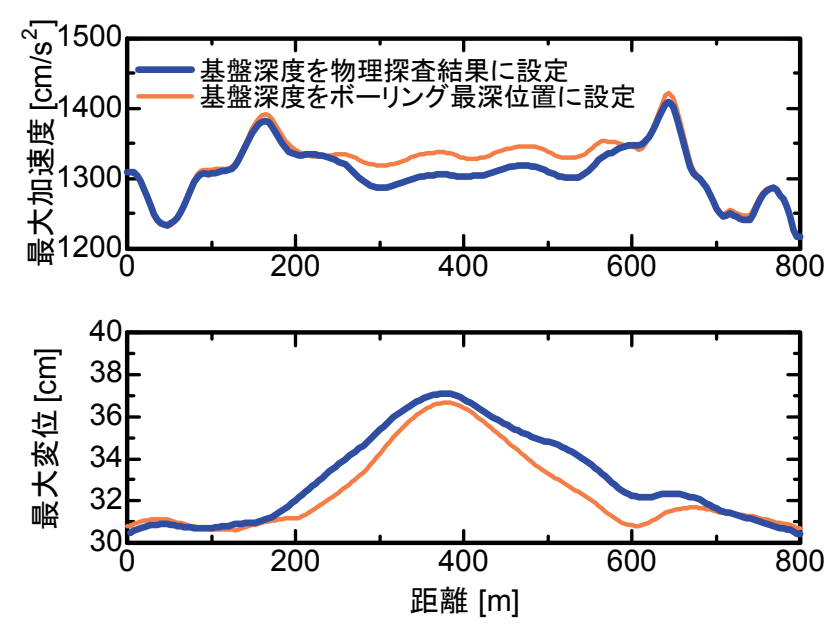

図-17 最大加速度, 最大変位分布

盤深度の差が $20 \mathrm{~m}$ 程度で, 応答值が $5 \%$ 程度の差であっ たが，地盤によっては，この差がさらに大きくなる可能 性もある.また，実地盤は非線形挙動を示すことや不整 形地盤では局所的に増幅する可能性があることなどを考 えると，常にこのような傾向となるわけではないと考え られる. 実設計を行う際に工学的基盤位置が非常に深く, ボーリングによって工学的基盤深度が得られない場合な どでは，今回のような物理探査手法を用いるなどして正 確な基盤位置を推定することが重要である.

\section{5. まとめ}

本報告では，シラスが厚く堆積する不整形地盤の地表 面地震動を評価するために，まず，ボーリング調査によ って工学的基盤位置が特定できない地域に対して, 微動 探査および重力探査を適用して基盤深度を推定した. 次 に, 推定した地盤構造に対して地盤の 2 次元動的 FEM 解析を行い, 地表面設計地震動を推定した. その結果, 以下に示寸知見が得られた.

（1）設計実務における工学的基盤の推定に，ボーリン グ調査に代わる手法として, 物理探査法が利用可能であ ることが確認された．具体的には，

・ 基盤深度既知点（array-A）において微動アレ一観測 による位相速度から基盤深度を推定したところ, 既 知の基盤深度とほぼ等しい結果を得た。これにより 
本手法はある程度の精度で基盤を推定できることが 確認された.

- 基盤深度未知点（array-B）における微動アレ一観測 結果を用いて基盤深度を推定したところ，深さ約 $110 \mathrm{~m}$ の位置に基盤が存在すること推定された.

・ アレー観測によって推定された地盤構造と微動の H/Vの結果を比較したところ, ほぼ調和的な結果を 得た. さらに複数観測点の $\mathrm{H} / \mathrm{V}$ から，この地域の基 盤構造の空間的な広がりを推定出来た.

- 重力観測による結果から, 対象地域の3次元基盤形 状が推定された.この結果は微動の結果と概ね一致 していた.

- 上記の微動探查, 重力探查および既往の土質調查結 果より, 総合的な判断を行い設計実務における工学 的基盤を推定した.

（2）上記(1)で推定された基盤形状を持つ地盤に対して 地震応答解析を行った. その結果, 軟弱地盤の塑性化や 不整形地盤の影響により, 地表面地震動は複雑な挙動を 示すことが確認された. 具体的には,

・ 対象地盤では, 軟弱シラス地盤の著しい塑性化によ り, 地表面地震動の加速度は頭打ち傾向を示し, 変 位が大きくなることが分かった。

- 地盤を線形として解析を行った結果, 工学的基盤を 誤って推定した場合と比較して，応答值には違いが 見られ，工学的基盤を正確に把握することの重要性 が示された。

上記の結果より, 微動探査, 重力探査は設計の際の工 学的基盤位置推定に有意な情報を与えることが示された。 また, 地表面地震動の評価にあたっては工学的基盤の推 定や不整形地盤における地震動の評価が重要であること も示された. 実設計において, 軟弱層が厚く堆積し, 何 らかの理由で通常のボーリング調査では工学的基盤を推 定できない場合については，さらにボーリング調查を続 けるよりも物理探査を行なう方がコス卜的に優れている 場合もあり得ると考えられる．このような場合には，本 報告のようにボーリング調査に代わる各種物理探査手法 を用いて総合的に基盤位置を推定することが望ましいと 考えられる. 一方で, 各種物理探査手法によっては, 現 場の状況等で, 設計で用いるのに十分な推定精度が得ら れない可能性も考えられる. しかし，そのような場合で あっても, 先に物理探査手法を用いて大まかな地下構造 を推定し，その結果を適切なボーリング調査計画に活か すことで，より効率的かつ経済的な調查が行なえる可能 性もあると考えられる。

謝辞 : 本報告は，鹿児島市の受託業務の一環で得た成果 を使用させていただきました。また，重力観測，微動観
測は東京工業大学大学院生, 伊藤慎一氏, 鈴木優斗氏, 小島康弘氏に協力していただきました. 記して厚く御礼 申し上げます。

\section{参考文献}

1) (財)鉄道総合技術研究所 : 鉄道構造物等設計標準・同解説 而震設計, 1999.

2) 高橋光昭, 那須誠, 及川浩 : 平成 5 年釧路沖地震による橋 梁の地震被害原因の考察, 土木学会年次学術講演概要集, 第3 部, Vol.48, pp.12-13，1993.

3) 菊入崇, 室野剛隆，永妻真治，西村昭彦：局所的な地盤条 件が鉄道高架橋の被害に与える影響について, 第 24 回地 震工学研究発表会講演論文集, pp.1105-1108, 1997.

4) 佐及宏一, 芦田譲, 菅野強: 建設・防苂技術者のための物 理探查, 森北出版, 1993.

5) Hayashi, K., and Suzuki, H. : CMP cross-correlation analysis of multichannel surface-wave data, Exploration Geophysics, Vol.35, pp.7-13, 2004.

6) Okada, H. : The Microtremor Survey Method, Geophysical Monograph Series, No. 12, translated by K. Suto, Society of Exploration Geophysicists, Tulsa, Oklahoma, USA, 2003.

7) 駒澤正夫 : 重力探査, 物理探査ハンドブック, 物理探査学 会, pp.433-468, 1998.

8) Horike, M. : Inversion of phase velocity of long-period microtremors to the S-wave-velocity structure down to the basement in Urbanized area, $J$. Phys. Earth, Vol.33, pp. 59-56, 1985.

9）紺野克昭：レイリ一波の分散曲線の近似計算法の提案と地 下構造推定一の応用，土木学会論文集，№.577/I-41，pp.89105, 1997.

10）時松孝次, 新井洋, 浅香美治 : 微動観測から推定した神戸 市住吉地区の深部 S 波速度構造と地震動特性, 日本建築学 会構造系論文集，No.491，pp.37-45，1997.

11）時松孝次, 新井洋: レイリー波とラブ波の振幅比が微動の 水平鋁直スペクトル比に与える影響, 日本建築学会構造系 論文集, No.511, pp.69-75, 1998.

12) 中村豊, 上野真 : 地表面震動の上下成分と水平成分を利用 した表層地盤特性推定の試み, 第 7 回日本地震工学シンポ ジウム講演集, pp.265-270, 1986.

13) Aki, K. Space and time spectra of stationary stochastic wave, with special reference to microtremor, Bull. Earthq. Res. Inst., Vol.35, pp. 415-456, 1957.

14）山中浩明, 石田寛: 遺伝的アルゴリズムによる位相速度の 逆解析, 日本建築学会構造系論文集, No.468, pp. 9-17, 1995.

15) 地質調查所編：日本重力 CD-ROM, 数值地質図 P-2, 地質 調查所, 2000.

16) 龍岡文夫, 福島伸二 : 砂のランダム繰り返し入力に対する 
応力〜歪関係のモデル化について(1), 生産研究, 30 巻 9 号, pp.356-359, 1978.

17) 安田進, 山口勇 : 種々の不擋乱土における動的変形特性, 第 20 回土質工学研究発表会, pp.539-542, 1985.

18）安田進，永瀬英生，小田真也，木辻浩二 : ステージ載荷が
動的変形特性に与える影響, 「地盤および土構造物の動的 問題における地盤材料の変形特性」に関する国内シンポジ ウム発表論文集，I-1，pp.127-132，1993.

(2008.4.1受付)

\title{
ESTIMATION OF NON-FLAT SUB-SURFACE STRUCTURE BY USING SOME GEOPHYSICAL EXPLORATIONS AND ITS APPLICATION TO SEISMIC DESIGN
}

\author{
Yuta NOGAMI, Kimitoshi SAKAI, Chika TAKAHASHI, \\ Yoshitaka MURONO, Hitoshi MORIKAWA and Tsutomu SATO
}

In seismic design for railway structures, it is essential to evaluate the effects of the subsurface structure appropriately. In order to estimate the ground structure, the boring investigation is mainly used. The boring investigation, however, may be difficult in case of certain circumstances, such as the soft ground condition, the deep engineering bedrock, the space condition for investigation and so on. In such cases, it is necessary to estimate the ground structure using other estimation methods. In this report, the authors presented another estimation method using microtremor and gravity survey. Moreover, we clarified the importance of structure estimation by calculating the ground motions based on the estimated subsurface structure. 